\title{
WELDABILITY OF Ti6Al4V TO AISI 2205 WITH A NICKEL INTERLAYER USING FRICTION WELDING
}

\author{
PREIZKUŠANJE VARIVOSTI PRI VARJENJU S TRENJEM Ti6A14V \\ IN AISI 2205 Z VMESNO PLASTJO NIKLJA
}

\author{
Ihsan Kirik \\ Batman University, Faculty of Engineering and Architecture, Department of Metallurgical and Materials Engineering, 72060 Batman, Turkey \\ alihsankirik@gmail.com \\ Prejem rokopisa - received: 2015-02-12; sprejem za objavo - accepted for publication: 2015-05-04
}

doi: $10.17222 /$ mit.2015.039

\begin{abstract}
The aim of this study was to friction weld dissimilar metals, i.e., Ti6Al4V to duplex stainless steel, with and without a nickel interlayer using a new method. The metallographic examinations of the weld were carried out and the strength of the joints was determined with tensile tests. The experimental results indicate that the Ti6Al4V and duplex stainless steel could be joined with a nickel interlayer. The highest tensile strength $(605 \mathrm{MPa})$ was obtained and the tensile strength of the joint was significantly increased with an increase of the rotation speed and the friction pressure.

Keywords: friction welding, titanium alloy, duplex stainless steel, nickel interlayer
\end{abstract}

Namen te študije je varjenje s trenjem različnih materialov Ti6Al4V in dupleks nerjavnega jekla, z in brez vmesne plasti niklja, z uporabo nove metode. Izvršeni so bili metalografski preizkusi zvara. Rezultati preizkusov kažejo, da je z vmesnim slojem niklja mogoče spajati Ti6Al4V in dupleks nerjavno jeklo. Z naraščanjem hitrosti vrtenja in pritiska pri trenju je mogoče doseči najvišjo natezno trdnost (605 MPa), hkrati pa narašča tudi natezna trdnost spoja.

Ključne besede: varjenje s trenjem, titanova zlitina, dupleks nerjavno jeklo, vmesni sloj niklja

\section{INTRODUCTION}

Materials such as low-carbon steels, ceramics and composites that are problematic and difficult to join using traditional welding methods can be joined by friction welding $(\mathrm{FW})$. One of the biggest advantages of FW is the production of a new material from pairs of dissimilar materials. ${ }^{1-2} \mathrm{FW}$ is an important manufacturing technique used in the machine construction and hydraulic industry, the automotive industry, and the industry for cutting and drilling tools. This technique has an important application area in welding technology, as it can join materials with different compositions if their sizes and shapes are appropriate, it does not have a limited melting event and it has a very low welding failure..$^{3-5}$

The joinability of $\mathrm{Ti}$ and its alloys to steels is extremely important because more and more of these metals are used together. ${ }^{6}$ When Ti alloys and stainless steels join mechanically, many intermetallic phases and different tension concentration areas occur at the intermediate of the joint, which then causes embrittlement and cracking. ${ }^{7}$ When Ti directly welds to the stainless steel, intermetallic compounds such as FeTi and $\mathrm{Fe}_{2} \mathrm{Ti}$ can occur at the joining area due to $\mathrm{Ti}$ and Fe having very little fusion capabilities. Besides, TiC may form since $\mathrm{Ti}$ is a strong carbide-forming element and also occurrences of these compounds cause a crispiness in the joining area. On the other hand, cracks may occur in the welding area due to the difference in the thermal conductivity between the Ti alloy and the steel. To avoid these negatives, the $\mathrm{Ni}$ interlayer diffusion welding method was used to combine the $\mathrm{TiC}_{4}$, the $\mathrm{Ti}$ alloy and the stainless steel, and sound joints were obtained, which had high strengths. ${ }^{8}$ The Ti-6Al-4V alloy and a microduplex stainless steel (AVESTA 2205) were joined using the diffusion-welding technique, and good results were obtained at temperatures as low as $800{ }^{\circ} \mathrm{C}$ in $30 \mathrm{~min} .{ }^{9}$ Aleman et al. ${ }^{10}$ studied pure $\mathrm{Ti}$ and $316 \mathrm{~L}$ stainless steel using the diffusion-welding technique and they stated that the $\sigma$-phase was observed on the stainless-steel side, $\mathrm{Fe}_{2} \mathrm{Ti}$ and $\mathrm{FeTi}$ in the inner side, and $\mathrm{Fe}_{2} \mathrm{Ti}_{4} \mathrm{O}$ oxide on the Ti side. Muralimohan et al. ${ }^{11}$ welded Ti and 304L stainless steel by FW and through a nickel interlayer, which is deposited by electroplating on stainless-steel substrates with a range of $100 \pm 3 \mu \mathrm{m}$. The joining of dissimilar materials such as aluminium, titanium, magnesium and their alloys to stainless steels was reported in ${ }^{1-14}$, but very limited studies are reported for titanium and its alloy to stainless steel using FW. Moreover, using an interlayer in FW is very limited, because it is difficult to keep the intermediate layer in the intermediate zone. TiAl and AISI 4140 steel were joined through FW with a copper insert layer and two-step joining of the FW was carried out to complete the joints by W. B. Lee et al. ${ }^{12}$ Madhusudhan and Venkata ${ }^{13}$ investigated the role of the nickel insert layer in the FW of maraging steel to lowalloy steel. To incorporate nickel as an interlayer, marag- 
Table 1: Chemical compositions of the test materials, in mass fractions $(w / \%)$

Tabela 1: Kemijska sestava preiskovanih materialov, v masnih deležih $(w / \%)$

\begin{tabular}{|c|c|c|c|c|c|c|c|c|c|c|c|}
\hline Materials & \multicolumn{10}{c|}{ Alloying elements, in mass fractions (w/\%) } \\
\hline & $\mathrm{Ti}$ & $\mathrm{C}$ & $\mathrm{Mn}$ & $\mathrm{P}$ & $\mathrm{Si}$ & $\mathrm{Cr}$ & $\mathrm{Al}$ & $\mathrm{Ni}$ & $\mathrm{Cu}$ & $\mathrm{V}$ & $\mathrm{Fe}$ \\
\hline Ti6Al4V & $\mathrm{Bal}$ & $=0.08$ & - & - & 0.15 & - & $5-6.50$ & - & - & $3.5-4.5$ & $=0.40$ \\
\hline AISI 2205 & - & $0.01-0.03$ & $1.68-2.00$ & 0.026 & - & $21-23$ & - & 3.37 & - & - & $\mathrm{Bal}$ \\
\hline Nickel & - & - & 0.007 & - & - & - & - & $\mathrm{Bal}$ & 0.01 & - & - \\
\hline
\end{tabular}

Table 2: The process parameters, used in the FW and the tensile test results according to these parameters

Tabela 2: Procesni parametri, uporabljeni pri FW in rezultati nateznega preizkusa pri teh parametrih

\begin{tabular}{|c|c|c|c|c|c|c|c|}
\hline \multirow[b]{2}{*}{$\begin{array}{c}\text { Sample } \\
\text { No. }\end{array}$} & \multicolumn{7}{|c|}{ Welding parameters } \\
\hline & $\begin{array}{c}\text { Rotation speed } \\
\left(\mathrm{m}^{-1}\right)\end{array}$ & $\begin{array}{l}\text { Fric. time } \\
\text { (s) }\end{array}$ & $\begin{array}{l}\text { Fric. press. } \\
\quad(\mathrm{MPa})\end{array}$ & $\begin{array}{c}\text { Forging } \\
\text { pressure (MPa) }\end{array}$ & $\begin{array}{l}\text { Forging time } \\
(\mathrm{s})\end{array}$ & $\begin{array}{l}\text { Without } \\
\text { Interlayer }\end{array}$ & $\begin{array}{l}\text { With Interlayer } \\
\text { Ten. Stren. } \\
\text { (MPa) }\end{array}$ \\
\hline N1 & 1500 & 6 & 150 & 200 & 4 & Failed & 380 \\
\hline $\mathrm{N} 2$ & 1500 & 6 & 125 & 200 & 4 & Failed & 326 \\
\hline N3 & 1500 & 6 & 100 & 200 & 4 & Failed & - \\
\hline N4 & 1800 & 6 & 150 & 200 & 4 & Failed & 420 \\
\hline N5 & 1800 & 6 & 125 & 200 & 4 & Failed & 605 \\
\hline N6 & 1800 & 6 & 100 & 200 & 4 & Failed & 180 \\
\hline Nickel & - & - & - & - & - & - & 450 \\
\hline AISI 2205 & - & - & - & - & - & - & 956 \\
\hline Ti6Al4V & - & - & - & - & - & - & 870 \\
\hline
\end{tabular}

ing steel and nickel were welded first. To maintain the 5 -mm length of interlayer the nickel was cut. Subsequently, low-alloy steel was welded on the nickel side of the joint.

The literature examined for using an insert layer in FW joining revealed two stages or the interlayer is kept at the interface using a different method. For this reason, the goal of this study is the successful joining of the Ti6Al4V titanium alloy and the AISI 2250 duplex stainless using FW single stage and with a nickel interlayer using a new technique. The strengths of the joints were determined by tensile tests and compared with those of base materials. Then, the microstructures in the welding zone were obtained and investigated using macro- and micro-photographs.

\section{EXPERIMENTAL PROCEDURES}

In this study, three materials with different properties were used in order to be joined using friction welding. The analysed chemical compositions of the materials are illustrated in Table 1. The duplex stainless steel and the Ti6Al4V alloy bars were provided commercially with a 12-mm diameter and were processed on a turning lathe machine according to the sizes shown in Figure 1a. Firstly, during the FW the most difficult stage while using the insert layer is to keep it at the interface. Thus, to avoid the escape of the interlayer, the surface of the duplex stainless steel is processed with a $10 \mathrm{~mm}$ diameter and a $3 \mathrm{~mm}$ depth, as shown in Figure 1a. Later, the nickel interlayer was placed on the forehead of the duplex stainless steel with the help of a press and then the welding was performed in a continuously driven FW machine using the parameters given in Table 2. After the
FW, in order to determine the microstructural changes to the samples that were friction welded, the axial crosssection of the joint was achieved by abrasive cutting and attached for polishing, and then the samples were etched in a chemical solution for the metallographic examination. The microstructure analyses of the joints were carried out with an optical microscope, and the scanning electron microscopy (SEM) and quantitative chemical analyses were performed with an energy-dispersive spectrometer (EDS). The friction-welded joints, with and without an interlayer, were tested for their tensile strength.

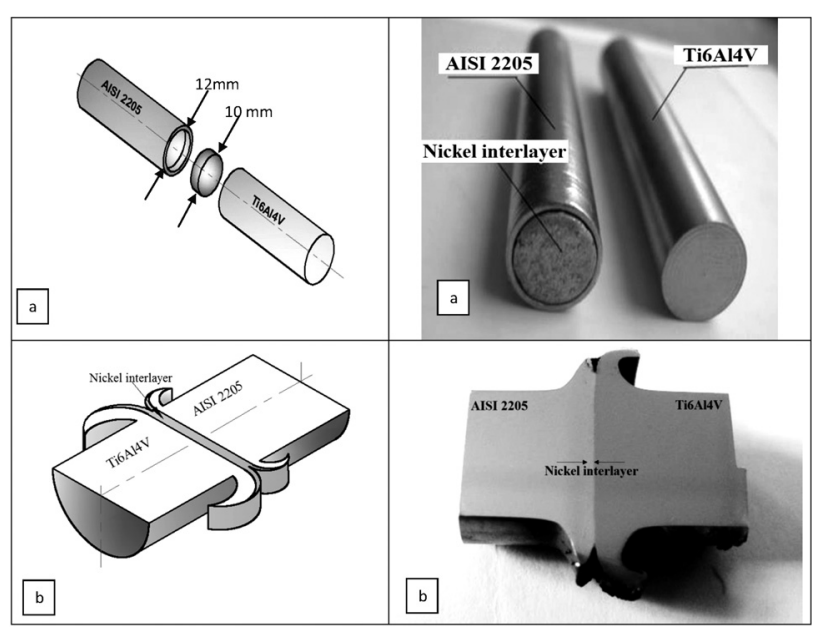

Figure 1: Schematic illustration of friction welded Ti6Al4V and AISI 2205 using: a) nickel interlayer, b) macrograph of cross-section of friction welded N5 sample

Slika 1: Shematski prikaz zvara pri trenju Ti6Al4V in AISI 2205: a) z uporabo vmesnega sloja niklja, b) makroposnetek preseka vzorca N5, zvarjenega s trenjem 


\section{RESULTS AND DISCUSSION}

\subsection{Examinations of microstructure}

A macro image of the FW joint N5 sample is shown in Figure 1b. It is evident that the joint is unsymmetrical and the flash dimensions of the Ti alloy are much larger than the stainless steel due to the decrease of the tensile yield strength of the Ti alloy with temperature being much more significant than that of duplex stainless steel, although at room temperature the situation is exactly reversed. ${ }^{15}$

The optical photographs taken from the FW joint N5 sample shows that the Ti6Al4V/AISI 2205 materials were successfully friction welded using a nickel interlayer (Figure 2). It is clear that there is a structural disorder and differently directed grains on the Ti6Al4V side near the nickel interlayer. Moreover, the FW of dissimilar metals, Ti6Al4V to duplex stainless steel, without an interlayer were tried so many times with different parameters, but the joints were not achieved due to brittle phase reaction and volume expansion.

The SEM micrograph for the N4 sample joined at a rotation of $1800 \mathrm{~min}^{-1}$, a 6-s friction time, a $150 \mathrm{MPa}$ friction pressure, a $200 \mathrm{MPa}$ forging pressure and a 4-s forging time is illustrated in Figure 3. From the micrograph it is clear that at the nickel and Ti6Al4V interface there were three different zones: $(\alpha$-Ti $+\beta$-Ti) of Ti6Al4V, $\beta$-phase and intermetallic phase in interface zone, nickel zone and invisible stainless steel zone. From ${ }^{14}$, when Ti alloys and the stainless-steel joint FeTi and $\mathrm{Fe}_{2} \mathrm{Ti}$ intermetallic phase occurred. Also, these phases adversely affect the quality of the joint. To eliminate the effects of this occurrence a nickel interlayer was used and the results confirmed that this is necessary. The concentrations of the elements across the interface zone are shown in Table 3 and the EDS graph is presented in Figure 3. From the EDS results of the N4 sample different amounts of $\mathrm{Al}, \mathrm{Si}, \mathrm{Ti}, \mathrm{V}, \mathrm{Ni}$ and Mo were obtained, but in the nickel some oxygen is obtained. As shown in Table 3, Ti and Ni have a high degree of diffusion in the

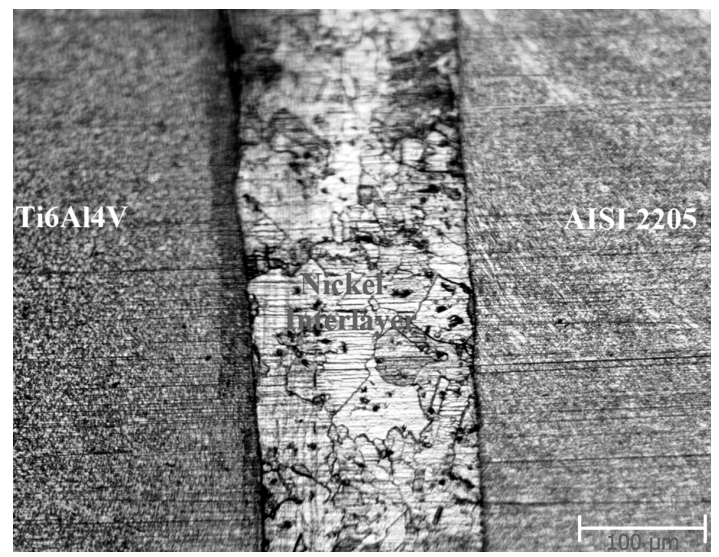

Figure 2: Optical microstructure of the interface of the N5 sample Slika 2: Mikrostruktura vmesnega sloja pri vzorcu N5 approximately $15-\mu \mathrm{m}$ region. Also, Ti diffused from Ti6Al4V to the nickel interlayer, the nickel diffused into the Ti alloy over the same distance. The FW of dissimilar materials with a nickel interlayer exhibits a wider plasticized zone in the middle of the welding interface. The variation of the alloying elements at the mutual interference is on account of the thermo-plastic stirring and the diffusion mechanism.

Table 3: Elementary variation rates from EDS analyses across the welding interface of the $\mathrm{N} 4$ sample

Tabela 3: Spreminjanje vsebnosti elementov določena z EDS analizo preko zvara vzorca $\mathrm{N} 4$

\begin{tabular}{|c|c|c|c|}
\hline \multirow{2}{*}{$\begin{array}{c}\text { Alloying } \\
\text { elements } \\
(w / \%)\end{array}$} & \multicolumn{3}{|c|}{ EDS points } \\
\cline { 2 - 4 } & 1 & 2 & 3 \\
\hline $\mathrm{O}$ & - & - & 12.47 \\
\hline $\mathrm{Al}$ & 6.799 & 5.755 & - \\
\hline $\mathrm{Si}$ & - & 0.799 & - \\
\hline $\mathrm{Ti}$ & 88.087 & 60.583 & 0.181 \\
\hline $\mathrm{V}$ & 4.025 & 1.950 & - \\
\hline $\mathrm{Ni}$ & 0.910 & 30.705 & 87.160 \\
\hline $\mathrm{Mo}$ & 0.189 & 0.208 & 0.188 \\
\hline
\end{tabular}

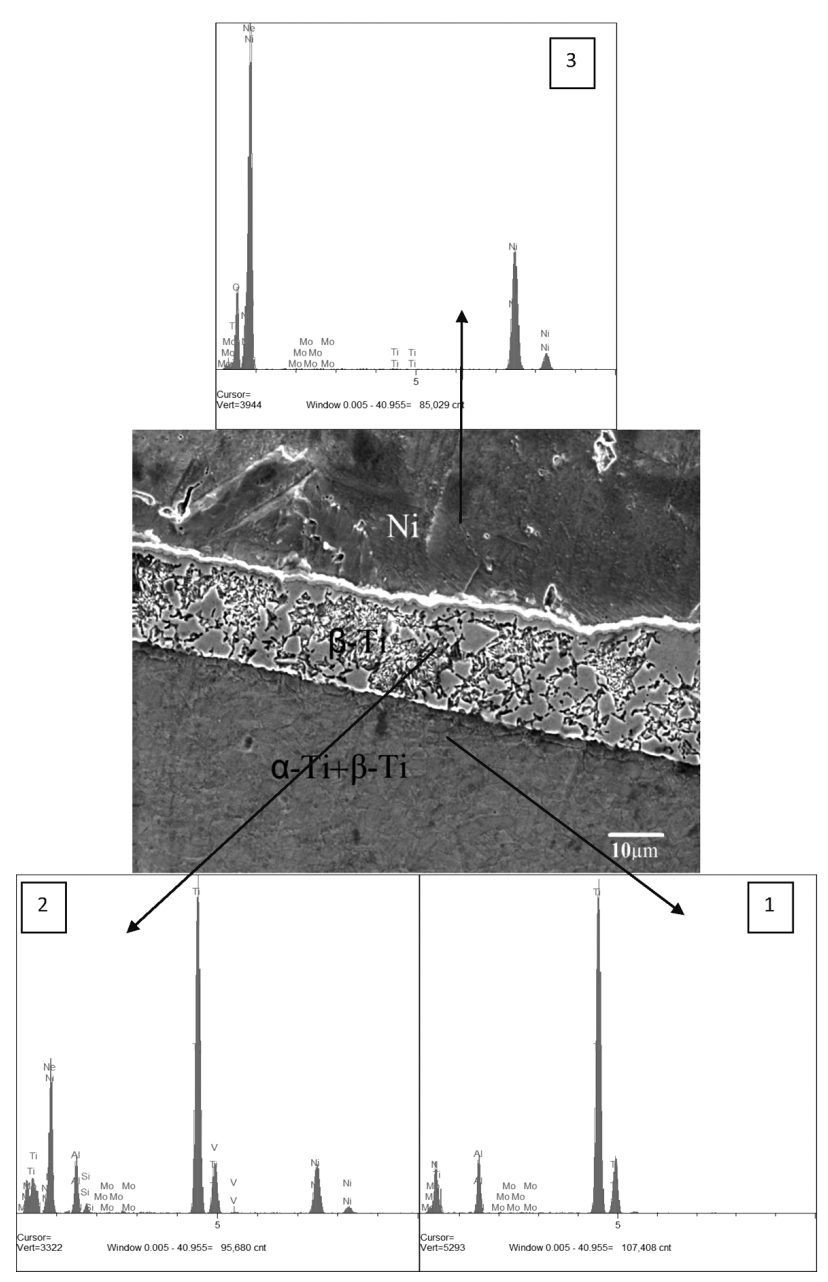

Figure 3: SEM photograph of the interface of the N4 sample and the EDS analysis

Slika 3: SEM-posnetek vmesnega sloja pri vzorcu N4 in EDS-analiza 


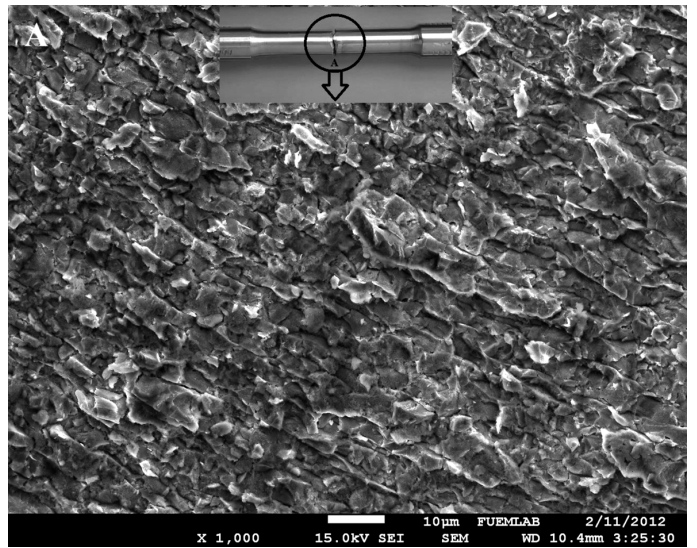

Figure 4: SEM photograph of fractured surface of N5 sample Slika 4: SEM-posnetek površine preloma vzorca N5

\subsection{Tensile testing}

The tensile strength of the joints was determined, as seen in Table 2, based on two different rotation speeds (1500 $\mathrm{min}^{-1}$ and $1800 \mathrm{~min}^{-1}$ ), three different friction pressures (100, 125 and 150) $\mathrm{MPa}$, a constant friction time (6s), a forging time (4s) and a forging pressure (200 MPa). The highest tensile strength (605 MPa) was obtained for the N5 sample. The tensile strength was increased by increasing the rotation speed with a constant friction time and pressure, and increasing the tensile strength results in heat input and a high plastic deformation. The fracture surface of the tensile test sample N5 is characterized with SEM to understand the failure mechanism. Figure 4 illustrates the fracturesurface morphologies taken from the centre of N5. It is clear that the fracture surface of the joint indicates a brittle cleavage fracture for Ti6Al4V/AISI 2205 stainless steel for different materials welding by FW using a nickel interlayer.

\section{CONCLUSION}

The effects of a nickel interlayer and the process parameters on the microstructure and tensile strength of friction welds between a Ti6Al4V alloy and AISI 2205 duplex stainless steel with and without an interlayer were studied. The following results were achieved:

Ti6Al4V and AISI 2205 were successfully joined by FW using a nickel interlayer.

In the event of FW between the Ti6Al4V and AISI 2205 the soundness of the joints was increased with a nickel interlayer and the rotation speed; but without an interlayer cracks occurred and it was not joined due to a brittle phase reaction and the volume expansion.

The highest tensile strength $(605 \mathrm{MPa})$ was obtained for the N5 sample joined at $1800 \mathrm{~min}^{-1}$, a 6-s friction time, $125 \mathrm{MPa}$ of friction pressure, $200 \mathrm{MPa}$ of forging pressure and a 4-s forging time. The tensile strength was increased when the rotation speed and the friction pressure increased.

\section{REFERENCES}

${ }^{1}$ N. Özdemir, Investigation of the mechanical properties of friction-welded joints between AISI 304L and AISI 4340 steel as a function rotational speed, Materials Letters, 59 (2005), 2504-2509, doi:10.1016/j.matlet.2005.03.034

${ }^{2}$ I. Krik, N. Özdemir, Weldability and joining characteristics of AISI 420/AISI 1020 steels using friction welding, Int. J. of Mat. Research, 8 (2013), 769-776, doi:10.3139/146,110917

${ }^{3}$ M. Sahin, Characterization of properties in plastically deformed austenitic-stainless steels joined by friction welding, Materials and Design, 30 (2009), 135-144, doi:10.1016/j.matdes.2008.04.033

${ }^{4}$ V. V. Satyanarayana, G. M. Reddy, T. Mohandas, Dissimilar metal friction welding of austenitic-ferritic stainless steels, J. of Mat. Proc. Tech., 160 (2005) 2, 128-137, doi:10.1016/ j.jmatprotec.2004.05.017

${ }^{5}$ H. Ates, M. Turker, A. Kurt, Effect of friction pressure on the properties of friction welded MA956 iron-based superalloy, Materials and Design, 28 (2007) 3, 948-953, doi:10.1016/j.matdes.2005. 09.015

${ }^{6} \mathrm{M}$. Ghosh, S. Chatterjee, Effect of interface microstructure on the bond strength of the diffusion welded joints between titanium and stainless steel, Materials Characterization, 54 (2005) 4-5, 327-337, doi:10.1016/j.matchar.2004.12.007

${ }^{7}$ M. Ghosh, S. Chatterjee, Characterization of transition joints of commercially pure titanium to 304 stainless steel, Materials Characterization, 48 (2002) 5, 393-399, doi:10.1016/S1044-5803(02) 00306-6

${ }^{8}$ P. He, J. C. Feng, B. G. Zhang, Y. Y. Qian, A new technology for diffusion bonding intermetallic TiAl to steel with composite barrier layers, Materials Characterization, 50 (2003) 1, 87-92, doi:10.1016/ S1044-5803(03)00122-0

${ }^{9}$ N. Orhan, T. I. Khan, M. Eroğlu, Diffusion bonding of a microduplex stainless steel to Ti-6Al-4V, Scripta Materialia, 45 (2001) 4 , 441-446, doi:10.1016/S1359-6462(01)01041-7

${ }^{10}$ B. Aleman, I. Gutiérrez, J. J. Urcola, The use of kirkendall effect for calculating intrinsic diffusion coefficients in a 316L/Ti6242 diffusion bonded couple, Scripta Materialia, 36 (1997) 5, 509-515, doi:10.1016/S1359-6462(96)00414-9

${ }^{11}$ C. H. Muralimohan, V. Muthupandi, K. Sivaprasad, Properties of friction welding titanium-stainless steel joints with nickel interlayer, Procedia Materials Science, 5 (2014), 1120-1126, doi:10.1016/ j.mspro.2014.07.406

${ }^{12}$ W. B. Lee, Y. J. Kim, S. B. Jung, Effects of copper insert layer on the properties of friction welded joints between TiAl and AISI 4140 structural steel, Intermetallics, 12 (2004) 6, 671-678, doi:10.1016/ j.intermet.2004.02.004

${ }^{13}$ G. Madhusudhan Reddy, P. Venkata Ramana, Role of nickel as an interlayer in dissimilar metal friction welding of maraging steel to low alloy steel, J. of Mat. Process. Tech., 212 (2012), 66-77, doi:10.1016/j.jmatprotec.2011.08.005

${ }^{14}$ B. Kurt, N. Orhan, E. Evin, A. Çalik, Diffusion bonding between Ti-6Al-4V alloy and ferritic stainless steel, Materials Letters, 61 (2007) 8-9, 1747-1750, doi:10.1016/j.matlet.2006.07.123

${ }^{15}$ P. Li, J. Li, M. Salman, L. Liang, J. Xioeng, F. Shang, Effect of friction time on mechanical and metallurgical properties of continuous drive friction welded Ti6A14V/SUS321 joints, Materials and Design, 56 (2014), 649-656, doi:10.1016/ j.matdes.2013.11.065 